\title{
C/EBP homologous protein (CHOP) deficiency ameliorates renal fibrosis in unilateral ureteral obstructive kidney disease
}

\author{
Shing-Hwa Liu ${ }^{1,2,3, *}$, Cheng-Tien Wu $\mathbf{u}^{1, *}$, Kuo-How Huang ${ }^{4,}{ }^{,}$, Ching-Chia Wang ${ }^{2}$, Siao- \\ Syun Guan ${ }^{5}$, Li-Ping Chen ${ }^{6}$, Chih-Kang Chiang ${ }^{1,7}$ \\ ${ }^{1}$ Institute of Toxicology, College of Medicine, National Taiwan University, Taipei, Taiwan \\ ${ }^{2}$ Department of Pediatrics, College of Medicine, National Taiwan University \& Hospital, Taipei, Taiwan \\ ${ }^{3}$ Department of Medical Research, China Medical University Hospital, China Medical University, Taichung, Taiwan \\ ${ }^{4}$ Department of Urology, College of Medicine, National Taiwan University, Taipei, Taiwan \\ ${ }^{5}$ Institute of Nuclear Energy Research, Atomic Energy Council, Taoyuan, Taiwan \\ ${ }^{6}$ Department of Dentistry, Taipei Chang Gang Memorial Hospital, Chang Gang University, Taipei, Taiwan \\ ${ }^{7}$ Department of Integrated Diagnostics \& Therapeutics, National Taiwan University Hospital, Taipei, Taiwan \\ *These authors have contributed equally to this work \\ Correspondence to: Chih-Kang Chiang, e-mail: ckchiang@ntu.edu.tw \\ Keywords: CHOP, renal fibrosis, unilateral ureteral obstruction, oxidative stress \\ Received: January 07, 2016 \\ Accepted: February 23, 2016 \\ Published: March 03, 2016
}

\section{ABSTRACT}

Renal tubulointerstitial fibrosis is an important pathogenic feature in chronic kidney disease and end-stage renal disease, regardless of the initiating insults. A recent study has shown that CCAAT/enhancer binding protein (C/EBP) homologous protein (CHOP) is involved in acute ischemia/reperfusion-related acute kidney injury through oxidative stress induction. However, the influence of CHOP on chronic kidney disease-correlated renal fibrosis remains unclear. Here, we investigated the role of CHOP in unilateral ureteral obstruction (UUO)-induced experimental chronic tubulointerstital fibrosis. The CHOP knockout and wild type mice with or without UUO were used. The results showed that the increased expressions of renal fibrosis markers collagen I, fibronectin, a-smooth muscle actin, and plasminogen activator inhibitor-1 in the kidneys of UUO-treated wild type mice were dramatically attenuated in the kidneys of UUO-treated CHOP knockout mice. CHOP deficiency could also ameliorate lipid peroxidation and endogenous antioxidant enzymes depletion, tubular apoptosis, and inflammatory cells infiltration in the UUO kidneys. These results suggest that CHOP deficiency not only attenuates apoptotic death and oxidative stress in experimental renal fibrosis, but also reduces local inflammation, leading to diminish UUO-induced renal fibrosis. Our findings support that CHOP may be an important signaling molecule in the progression of chronic kidney disease.

\section{INTRODUCTION}

Renal tubulointerstitial fibrosis is an important hallmark during the progression from chronic kidney disease (CKD) to the end-stage renal disease (ESRD). Fibrosis is the final common pathway of the majority of chronic renal diseases regardless of the initiating insult [1]. Accumulating evidence indicates that tubulointerstitial injury is a more consistent predictor of renal functional decline than glomerular injury $[2,3]$. Renal tubulointerstitial fibrosis reflects the imbalance of different mechanisms including renal cells apoptosis, inflammatory cells infiltration, and oxidative stress generation. However, the molecular mechanisms of renal tubulointerstitial fibrosis are still not well understood. Studies aiming to elucidate the potential mechanisms of renal fibrosis are urgently needed to facilitate the discovery of therapies capable of reversing renal fibrosis and improving CKD and ESRD. Endoplasmic reticulum (ER) stress has been shown to be triggered by cellular insults including starvation, genetic mutation, disturbance of protein turnover, and inflammation, and may be 
associated with diseases such as diabetes, cardiomyopathy, and neuron degeneration disease [4-8]. Furthermore, several studies identified that ER stress might take part in the process of cholestasis-induced liver fibrosis, cystic fibrosis, pulmonary fibrosis, and renal fibrosis [4, 9-11].

The CCAAT/enhancer binding protein $(\mathrm{C} / \mathrm{EBP})$ homologous protein (CHOP), also known as $\mathrm{C} / \mathrm{EBP} \beta$ DNA damage-inducible gene 153 (GADD153), or DNA damage inducible transcript 3 (DDIT3), is an important transcription factor that contributes to numerous cellular functions such as apoptosis, inflammation, and differentiation [12-15]. CHOP is one of highest inducible genes during ER stress. In several animal disease models like as diabetes, neuron degeneration, and ischemia/ reperfusion in brain or kidney, $\mathrm{CHOP}$ is involved in cellular apoptosis and organ dysfunction [16-19]. CHOP has also been found to participate in $\mathrm{PGE}_{2}$-stimulated IL-8 production in cystic fibrosis bronchial epithelial cells [9], the regulation of cell-matrix adhesion in podocytes [20], and oxidative stress-related apoptosis in neuroblastoma cells [21]. CHOP can induce reactive oxygen species (ROS) formation and inflammation during acute renal ischemia-reperfusion ( $\mathrm{I} / \mathrm{R})$ injury [22]. It is expected that prolonged ROS generation and inflammation in acute renal injury may also contribute to renal fibrosis chronically. However, the role of CHOP activation during ER stress in obstruction-induced renal fibrosis is still unclear. To address this issue, we hypothesized that ER stress-related CHOP is involved in the pathology of chronic renal fibrosis. In this study, CHOP-knockout mice subjected to unilateral ureteral obstruction (UUO), a conventional approach for inducing renal fibrosis, resulting in accumulation of extracellular matrix, prolonged oxidative stress, and acceleration of interstitial inflammation [2325], were used. We demonstrated that CHOP deficiency effectively ameliorated obstruction-induced renal fibrosis via the attenuation of profibrotic factors, oxidative stress, and inflammatory cells infiltration.

\section{RESULTS}

\section{CHOP deficiency attenuated renal fibrosis in a mouse UUO model}

As shown in Figure 1A, Western blotting displayed that $\mathrm{CHOP}$ expression was upregulated in the wild type

A
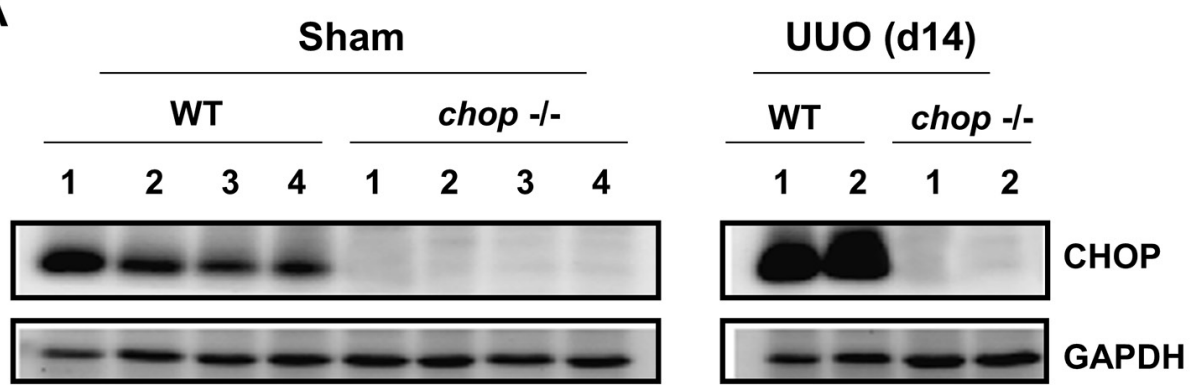

B

a

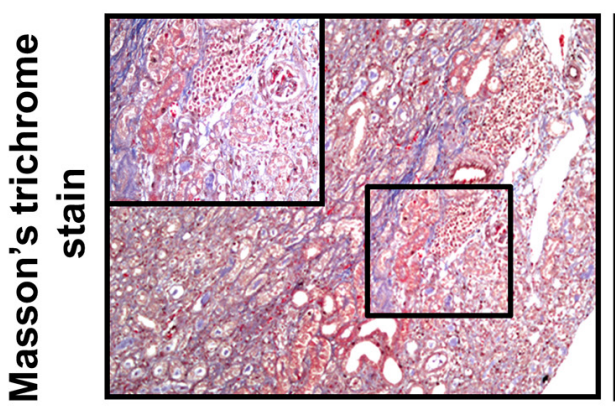

UUO WT (d14)

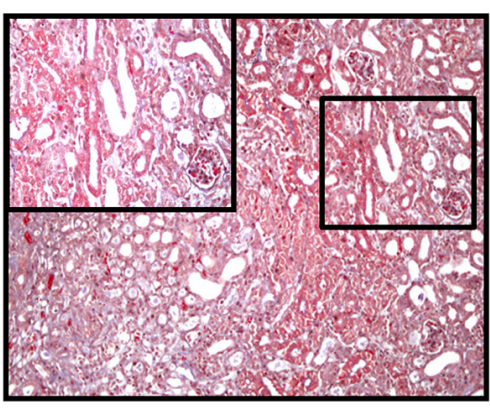

UUO chop -/- (d14) b

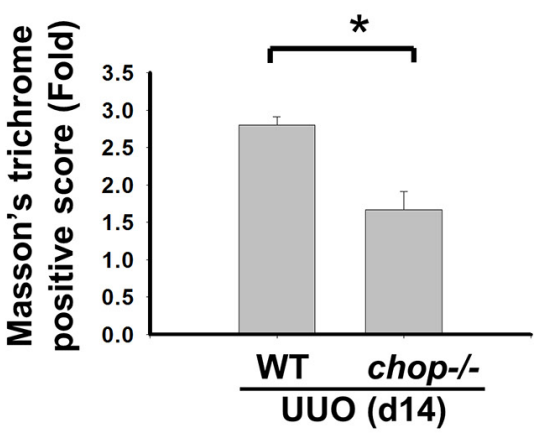

Figure 1: CHOP deficiency alleviates UUO-induced collagen deposition in fibrotic kidney. Wild type or $C H O P$ knockout C57BL/6 mice were surgically administered with UUO surgery for 14 days. CHOP protein expression were assessed by Western blotting assay A. Results are representative of at least three independent experiments from four mice per group. Pathological changes of renal fibrosis in UUO treatment of wild type and $C H O P$ deficiency mice were performed by the Masson's trichrome staining B. The quantification was shown in (B-b). Data are presented as mean \pm SEM (n=4/group) for three independent experiments. $* P<0.05$, UUO (day 14 ) wild type vs CHOP-/-. WT: wild type; $C H O P-/-:$ CHOP deficiency. 
(WT) mice with UUO on day 14. In KO mice, neither sham control nor the UUO kidney expressed CHOP on day 14 (Figure 1A). Moreover, Masson's Trichrome staining revealed that kidneys of WT mice possess obvious tubulointerstitial collagen deposition in response to UUO, while only mild collagen deposition is observed in the kidneys of KO mice with UUO (Figure 1B-a and 1B-b). As shown in Figure 2, the expressions of both fibronectin, a major ECM protein and a fibroblast chemoattractant [26], and $\alpha$ SMA, a tubulointerstitial fibrosis marker in UUO kidney [2], were barely detectable in the kidneys of sham WT or sham KO mice, but prominently elevated in the WT mice after UUO on day 14. On the contrary, both fibronectin and $\alpha$ SMA expressions were significantly decreased in the kidneys of KO mice after UUO on day 14, as compared with WT mice with UUO (Figures 2A and 2B). Similarly, Western blotting also showed that the increased expressions of collagen I, fibronectin, $\alpha \mathrm{SMA}$, and plasminogen activator inhibitor-1 (PAI-1) in UUO kidneys were significantly reversed in the $C H O P \mathrm{KO}$ mice (Figure 3). These results suggest that $C H O P$ deficiency effectively restores the UUO-induced renal fibrosis.

\section{CHOP deficiency decreases renal cell apoptosis in UUO kidney}

Tubular apoptosis is a critical feature of renal implications in the development of tubular functional atrophy or chronic progressive renal disease [24, 27, 28]. CHOP is known as an inducible gene after growth arrest, DNA damage and transcriptional regulator inducing the ER stress-correlated apoptosis [29]. As shown in Figure $4 \mathrm{~A}$ and $4 \mathrm{~B}$, the increased apoptosis was obviously observed in the kidneys of WT mice with UUO on day 14, but not incited in $\mathrm{KO}$ mice. Furthermore, the increase of Pro-caspase 12 and Bcl-2 cleavage in the kidneys of WT mice with UUO obviously observed than in $\mathrm{KO}$ mice on day 14 (Figure 4C). These results indicated that CHOP
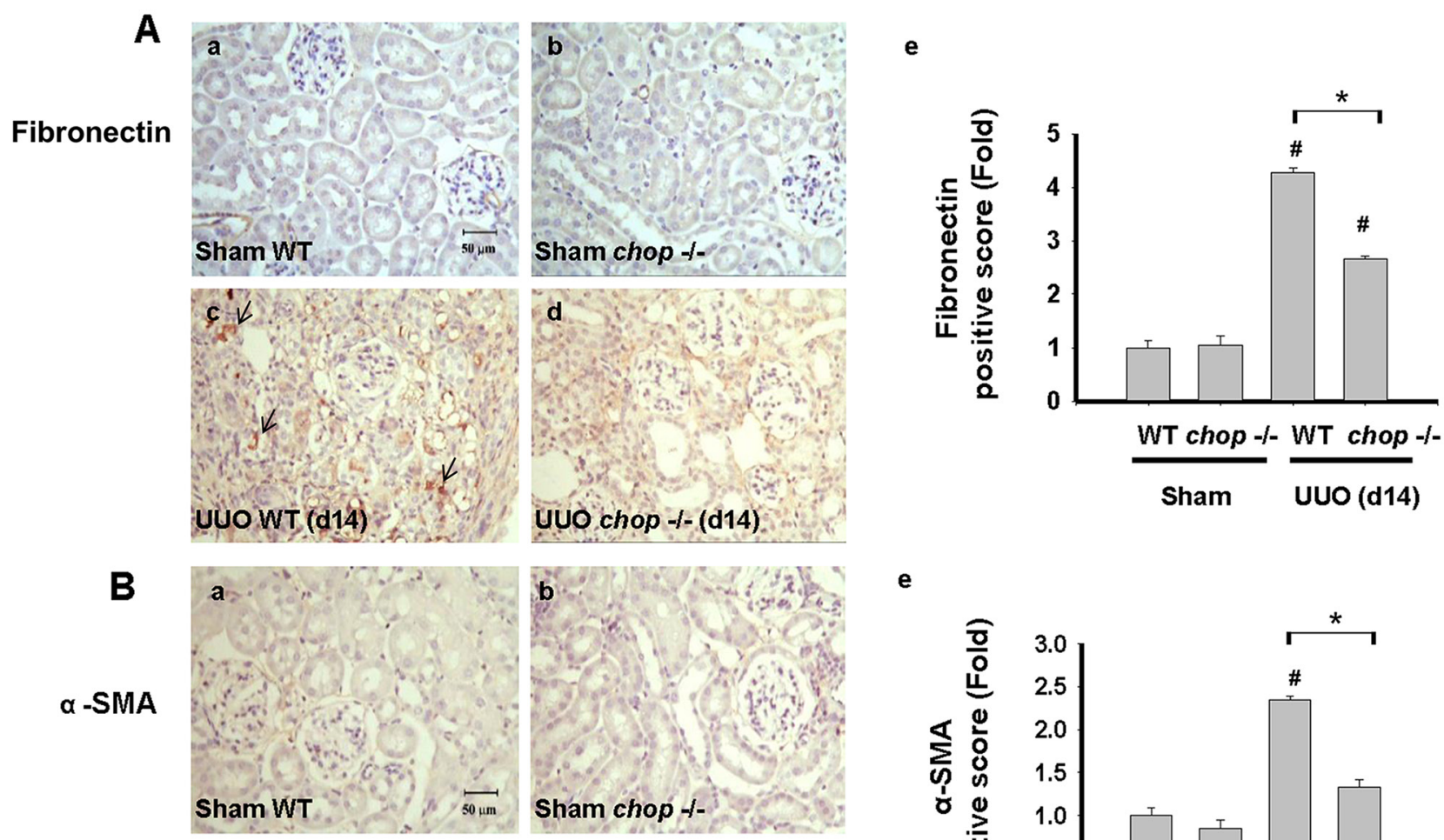

e
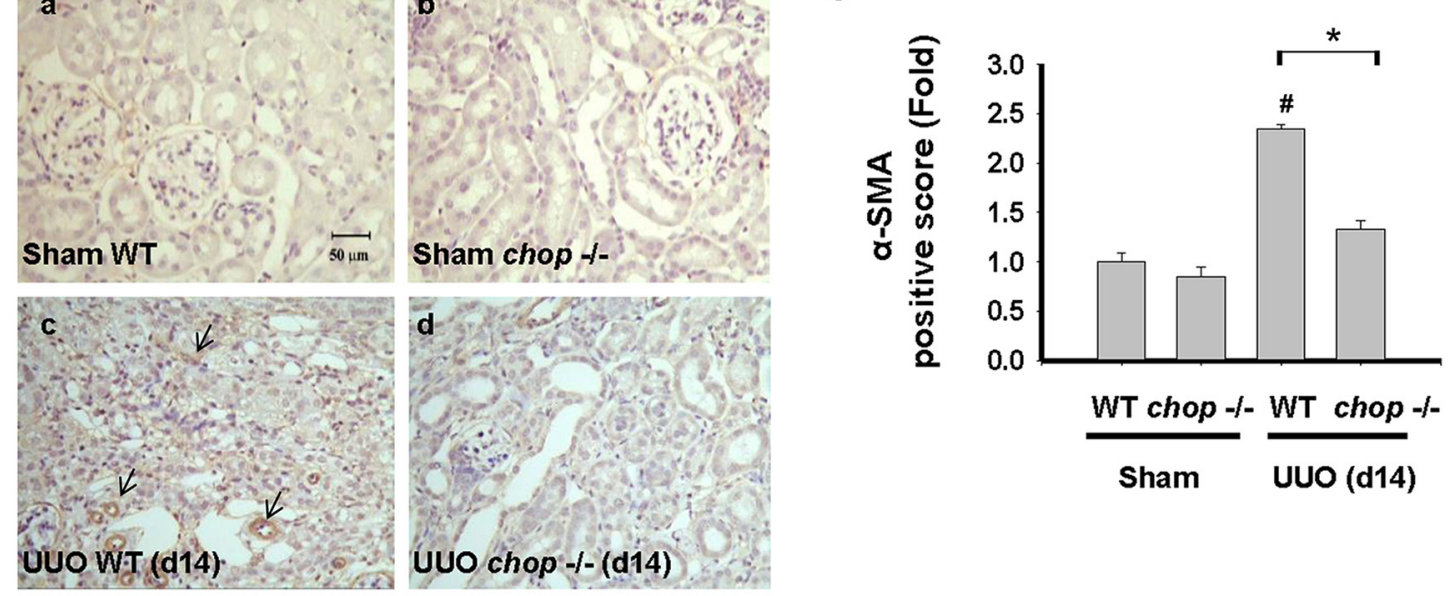

Figure 2: CHOP deficiency mitigates UUO-induced FN and $\boldsymbol{\alpha}-\mathrm{SMA}$ expression. Wild type or $C H O P$ knockout C57BL/6 micewere surgically administered with UUO surgery for 14 days. Sham control was the contralateral normal kidneys. Pathological changes of renal fibrosis were displayed by the IHC staining for fibronectin A-a. to A-d. and $\alpha$ SMA, B-a. to B-d. The quantification was showed in B-e. Data are presented as mean \pm SEM ( $\mathrm{n}=4$ /group) for three independent experiments. $\# P<0.05$, vs wild type sham control. $* P<0.05$, UUO (day 14) wild type vs CHOP-/-. WT: Wild type; $C H O P-/-$ CHOP deficiency; $\alpha$-SMA: $\alpha$-smooth muscle actin. 
deficiency decreases renal cell apoptosis in chronic renal fibrosis.

\section{CHOP deficiency abated reactive oxygen species (ROS) production in UUO kidney}

ROS is known as a key mediator involved in the obstructive-induced renal fibrosis [30-32]. Our previous study indicated that CHOP may effectively prevent hypoxia/reperfusion-induced ROS injury. Consequently, we tested whether $C H O P$ deficiency is involved in the attenuation of ROS production in chronic renal fibrosis. As shown in Figure 5A, the product of lipid peroxidation, malondialdehyde (MDA) was significantly increased in UUO kidneys of WT mice but not in KO mice on day 14. Moreover, NADPH oxidase isoform NOX-4 protein expression was increased, but superoxide dismutase (SOD1 and SOD2) and catalase protein expressions were decreased in UUO kidneys of WT mice, which are shown to counteract in $\mathrm{CHOP}$ deficiency mice (Figure 5B and $5 \mathrm{C})$. These results indicated that $C H O P$ deficiency can attenuate UUO-induced renal fibrosis via attenuating oxidative stress.

\section{CHOP deficiency diminished inflammation cells recruitment but did not activate $N F \kappa B$ or C/EBP $\beta$ expression in obstructive kidney}

Inflammation is another important feature, contributing to the excess production and deposition of collagen in tissue fibrosis [33, 34]. CHOP signaling has also been suggested to be involved in the inflammation induction by pulmonary cystic fibrosis or myocardial reperfusion injury $[9,35]$. We next elucidated whether CHOP deficiency contributed to inflammatory cells, including macrophages and neutrophils, infiltration in the UUO kidney. As shown in Figure 6A, F4/80, a macrophage marker, positive cells were detected in the UUO kidneys of WT mice. On the contrary, F4/80 positive stain cells are less frequently detected in the kidneys of CHOP deficiency mice. Similarly, Ly6G, the neutrophil marker, is also found to be increased in the UUO kidneys
A

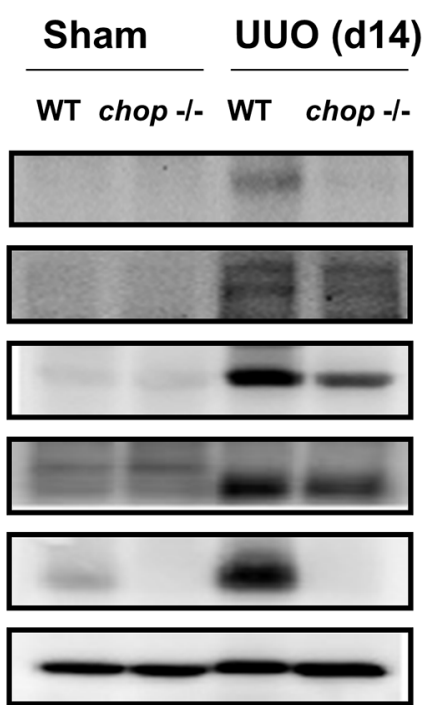

B

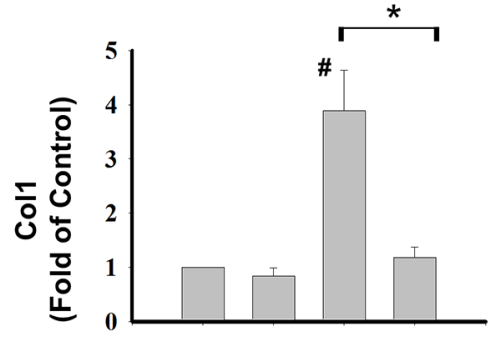

Col-1
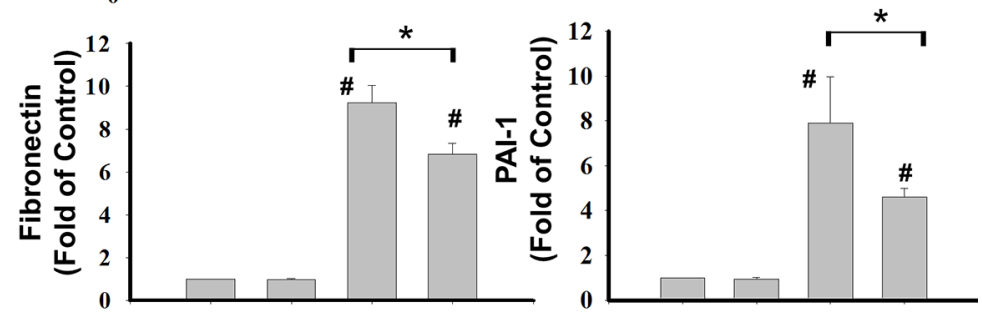

CHOP

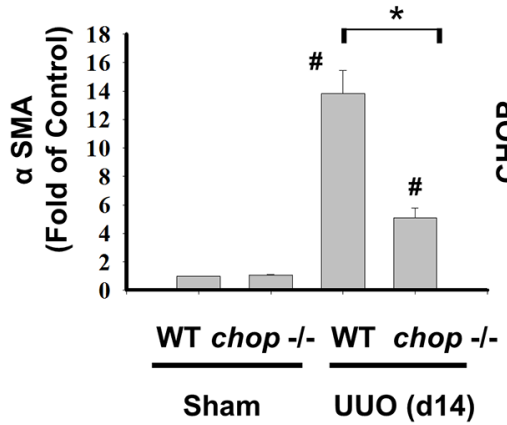

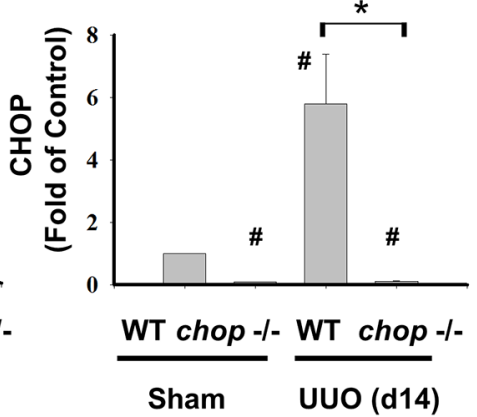

Figure 3: CHOP deficiency attenuates fibrosis-related markers in the kidneys of UUO mice. Wild type or $C H O P$ knockout C57BL/6 micewere surgically administered with UUO surgery for 14 days. Sham control was the contralateral normal kidneys. The expressions of renal fibrosis markers collagen I (Col-1), fibronectin, $\alpha$-smooth muscle actin ( $\alpha \mathrm{SMA})$, and plasminogen activator inhibitor-1 (PAI-1) and CHOP were performed by the Western blotting A. The quantification was shown in B. Data are presented as mean $\pm \mathrm{SEM}(\mathrm{n}=5 /$ group) for three independent experiments. $\# P<0.05$, vs wild type sham control. ${ }^{*} P<0.05$, UUO (day 14 ) wild type vs $C H O P-/-$. WT: Wild type; $\mathrm{CHOP-/-:} \mathrm{CHOP}$ deficiency. 
of WT mice on day14 but not in KO mice (Figure 6B). These results indicated the infiltration of macrophages and neutrophils in the kidneys at day 14 after UUO decreased in CHOP deficiency mice.

We next ascertained whether Chop deficiency contributed to the NF- $\mathrm{B}$ suppression. An increase in phosphorylation of NF- $\mathrm{NB}-\mathrm{p} 65$ and a decrease in $\mathrm{C} /$ EBP $\beta$ expression were observed in UUO kidneys of WT mice on day 14, but Chop depletion did not activate the NF- $\kappa \mathrm{B}$ activation and $\mathrm{C} / \mathrm{EBP} \beta$ expression in UUO kidneys (Figure 7).

\section{DISCUSSION}

CHOP is known as an important apoptosisinduced factor in the ER stress network during numerous disease conditions, including diabetes [18,
36], Parkinson's disease [37], and renal dysfunction [38]. The down-regulation of Bcl-2 has been suggested as one mechanism of CHOP-related apoptosis [39]. Under ER stress, CHOP downregulates the expression of $\mathrm{Bcl}-2$, sensitizing cells to apoptosis, resulting in renal functional and pathological damages in acute kidney injury [22, 40]. JNK activation has been implicated in ER stress-related apoptosis associated with $\mathrm{CHOP}$ via regulating the expression and activity of pro- and antiapoptotic proteins, including Bcl-2 family members [41]. Consistent with our findings, CHOP deficiency effectively ameliorates renal cell apoptosis via the inhibition of Bcl-2 down-regulation and JNK activation during obstruction-induced nephropathy. These results suggested that ER stress-induced $\mathrm{CHOP} / \mathrm{JNK} / \mathrm{Bcl}-2$ signals may contribute chronic renal fibrosis in UUO model.
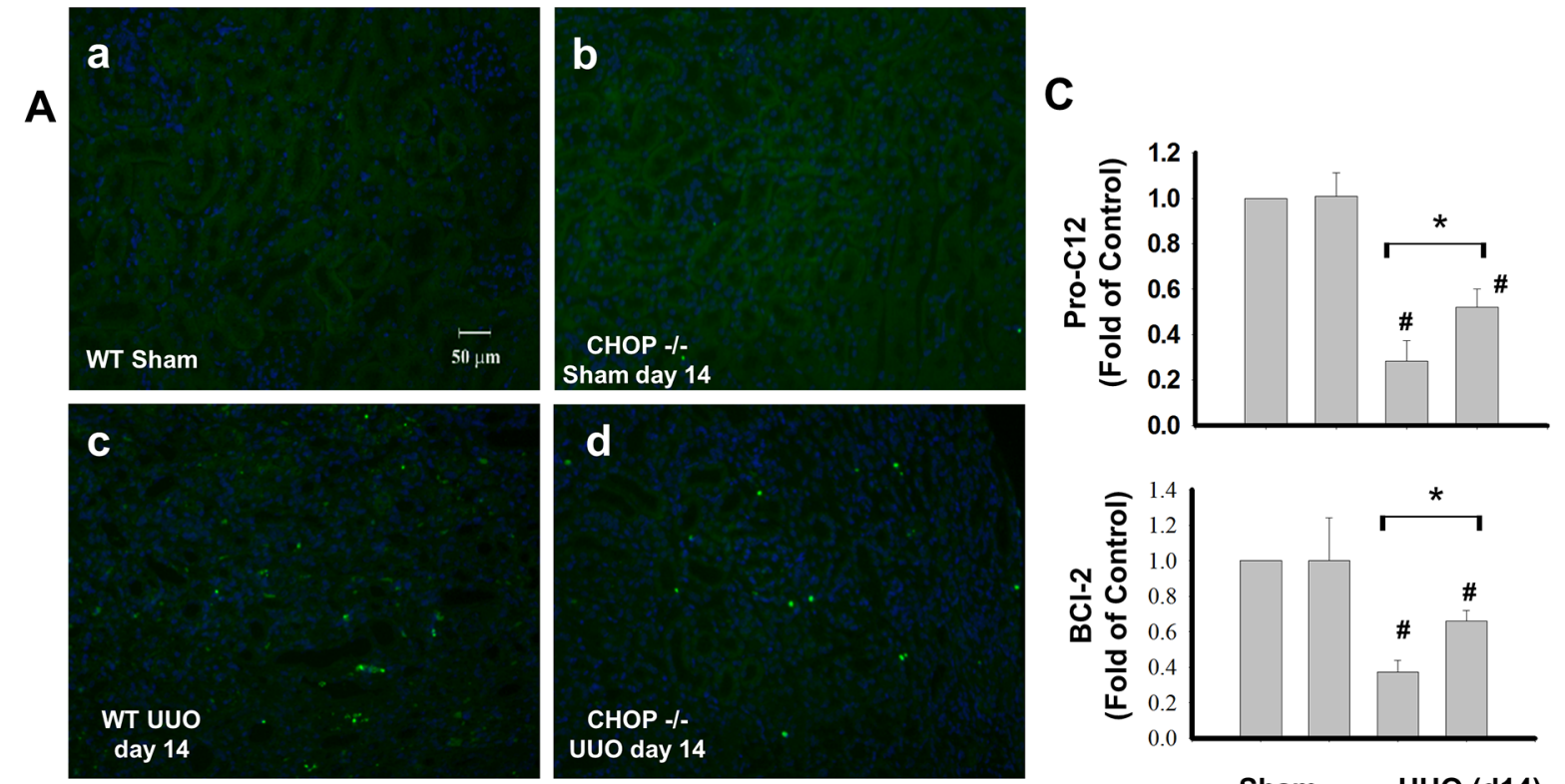

B
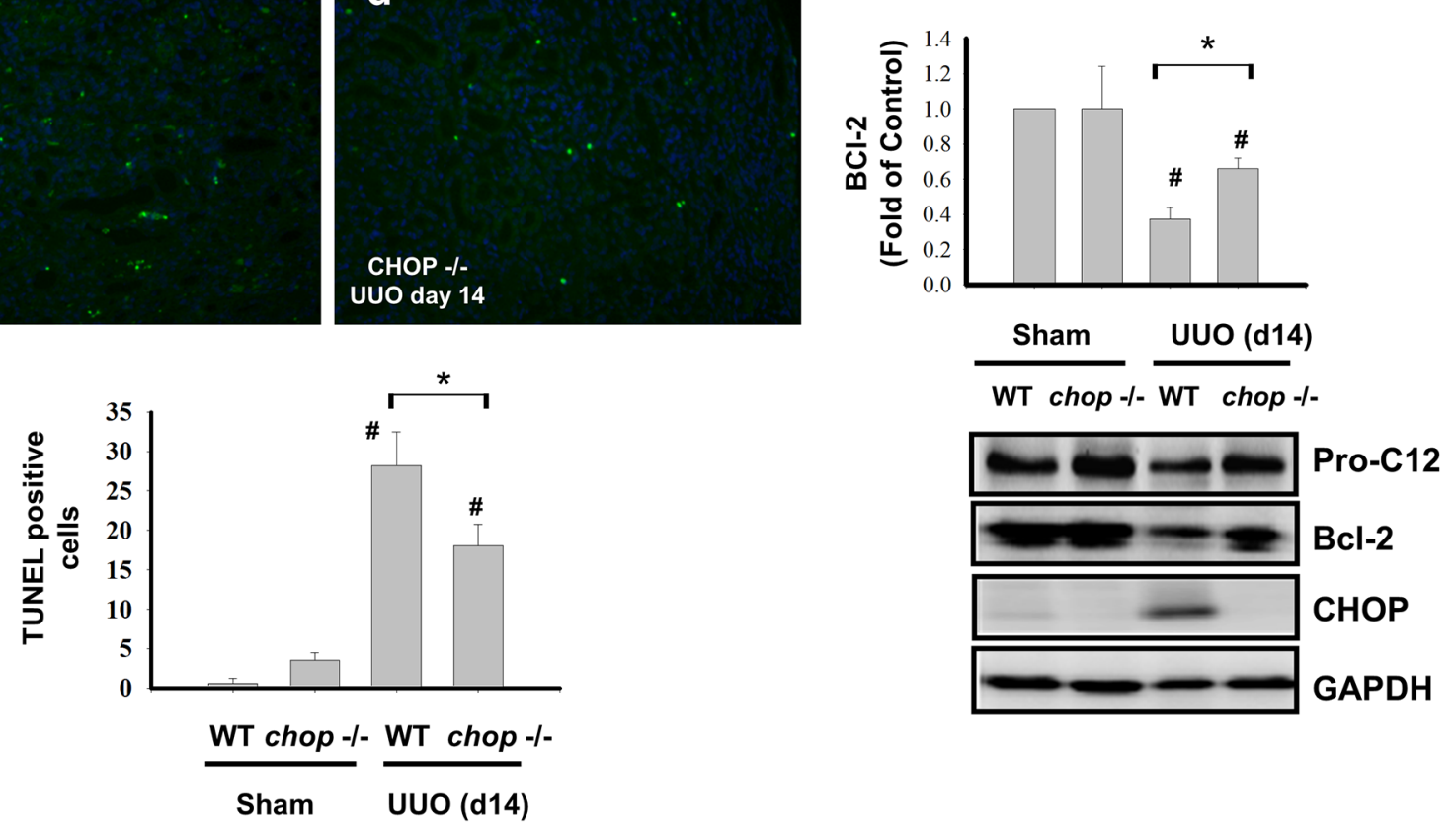

Figure 4: CHOP deficiency attenuates renal cell apoptosis in the kidneys of UUO mice. Wild type or $C H O P$ knockout C57BL/6 micewere surgically administered UUO for 14 days. Sham control was the contralateral normal kidneys. Apoptotic cells in renal were assessed by the TUNEL staining A. Quantification was counted by blinding selection for 10 random visual fields, using $200 \mathrm{X}$ magnification B. The expressions of apoptosis-related proteins Pro-caspase 12, Bcl-2, and CHOP were performed by the Western blotting C. Data are presented as mean \pm SEM ( $\mathrm{n}=5$ /group) for three independent experiments. $\# P<0.05$, vs wild type sham control. $* P<0.05$, UUO (day 14) wild type vs CHOP-/-. WT: Wild type; $C H O P-/-:$ CHOP deficiency. 
Cumulating evidence suggested that CHOP was involved in the regulation of inflammatory responses, such as prostaglandin $\mathrm{E}_{2}$-stimulated interleukin (IL)8 production, caspase-11-correlated IL-1 $\beta$ production, and caspase-11-related lipopolysaccharide-induced inflammation [9, 12, 42]. IL-8 is known as a major neutrophil chemo-attractant in various tissues [43-46]. Inflammatory cell infiltration, including macrophages and neutrophils, is one of the main features in the kidney of UUO model $[24,47,48]$. In this study, we found that both Ly6G, a neutrophil marker, and F4/80, a macrophage marker, are markedly increased in the UUO kidneys of wild-type mice, but it was dramatically diminished in $C H O P$ knockout mice. These results suggest that CHOP deficiency may have the potential to attenuate inflammatory cells infiltration during the obstructiveinduced nephropathy. NF- $\mathrm{B}$ can be activated in the kidneys of UUO animal model and is involved in the tubulointerstitial cellular pro-inflammation and interstitial fibrosis [27, 49, 50]. Over-expression of CHOP can block both cyclosporin A and tacrolimus (FK506)-induced NF$\kappa \mathrm{B}$ activation [51]. $\mathrm{CHOP}$ is also found to interact with $\mathrm{C} / \mathrm{EBP}$ family proteins like $\mathrm{C} / \mathrm{EBP} \beta$ and then alters the $\mathrm{NF}-\kappa \mathrm{B}$ activation $[16,52]$. These results suggested that CHOP signaling might possess inhibitory potential in NF$\kappa \mathrm{B}$ activation and $\mathrm{C} / \mathrm{EBPs}$ function. In our experiments, unexpectedly, neither $\mathrm{NF}-\kappa \mathrm{B}$ activation nor $\mathrm{C} / \mathrm{EBP} \beta$ expression was activated in the UUO kidneys of $\mathrm{CHOP}$ knockout mice as compared with wild-type mice. These results suggest that the attenuation of inflammation and renal fibrosis during $\mathrm{CHOP}$ deficiency may not be correlated to $\mathrm{NF}-\kappa \mathrm{B}$ or $\mathrm{CEBP} / \beta$ signaling pathway.

Oxidative stress is a crucial feature implicated in renal fibrosis, epithelial-mesenchymal transition (EMT), and inflammation induction $[31,53]$. Cumulative evidence indicated that NOX4-based NADPH oxidase is an important factor for oxidative stress induction and pathological alterations in liver and lung fibrosis as well
A

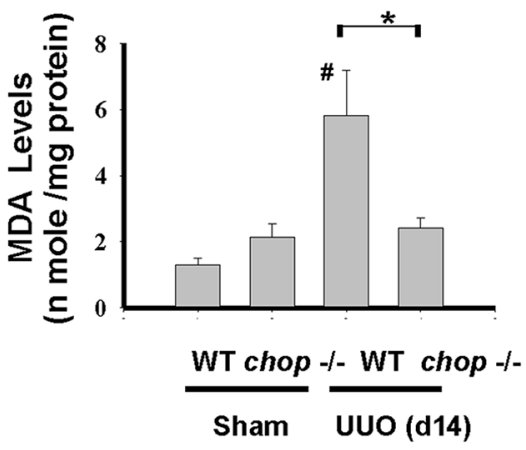

B

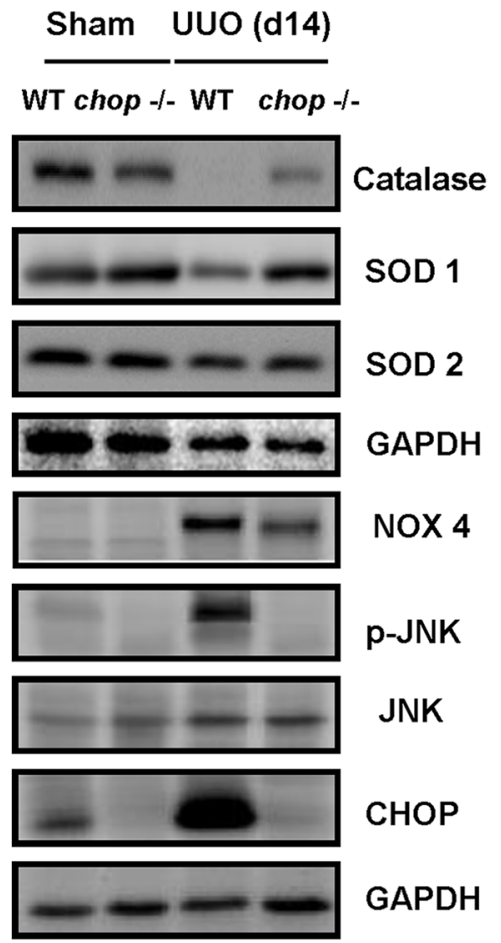

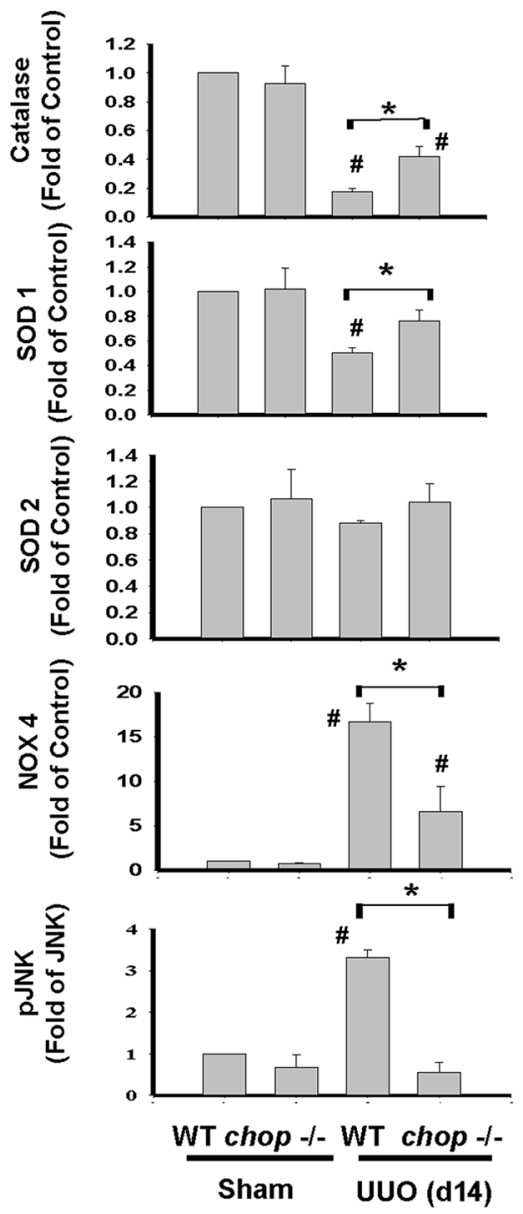

Figure 5: CHOP deficiency abates oxidative stress in the kidneys of UUO mice. Wild type or CHOP knockout C57BL/6 micewere surgically administered UUO for 14 days. Sham control was the contralateral normal kidneys. Oxidative stress was assessed by the MDA stain in A. The expressions of oxidative-related proteins Catalase, superoxide dismutase 1 (SOD1), SOD2, NADPH oxidase 4 (NOX4), JNK and its phosphorylated form, and CHOP were performed by the Western blotting B. Quantification was shown in C. Data are presented as mean \pm SEM ( $\mathrm{n}=5$ /group) for three independent experiments. $\# P<0.05$, vs wild type sham control. $* P<0.05$, UUO (day 14 ) wild type vs $C H O P-/-$. WT: Wild type; $C H O P-/-:$ CHOP deficiency. 
as diabetic nephropathy [54-56]. NOX-4 has been found to be involved in salubrinal (an eIF $2 \alpha$ dephosphorylation inhibitor)-enhanced cisplatin-induced oxidative stress and acute nephrotoxicity [57]. ER stress inhibitors can effectively reduce ER stress induction (including CHOP), increased NOX-2/NOX-4 expression, oxidative stress induction, and endothelial cell dysfunction in tunicamycin-treated endothelial cells [58]. Inhibition of ER stress has also been found to reverse oxidative stress induction, NOX-4 expression, and NADPH oxidase activity in diabetic cardiac damage and microvascular dysfunction [59]. Pedruzzi et al. observed that the Nox4 deficiency prevented the UPR markers expression, including CHOP and Bax proteins, and cell death induction in 7-ketocholesterol-treated aortic smooth muscle cells [60]. These findings implied that NOX4 is one of the important oxidative stress signals induced by ER stress, which causes pathological insults. Moreover, overexpression of manganese SOD was capable of attenuating cadmium-induced $\mathrm{CHOP}$ protein expression and apoptosis in LLC-PK1 cells; overexpression of catalase did not reduce cadmium-induced CHOP expression, but could inhibit apoptosis [61]. Santos et al. recently suggested that oxidative stress might occur both upstream and downstream of the ER stress response, including the expression of ATF4, Nrf2, and CHOP, and the oxidases like as Nox2/Nox4 may couple ER stress to cellular redox signals, which is alone with the prosurvival or proapoptotic outcome [62]. In this study, we found that lipid peroxidation and NOX-4 expression were markedly increased and SOD1 and catalase were dramatically decreased in UUO kidneys of wild-type mice but not in
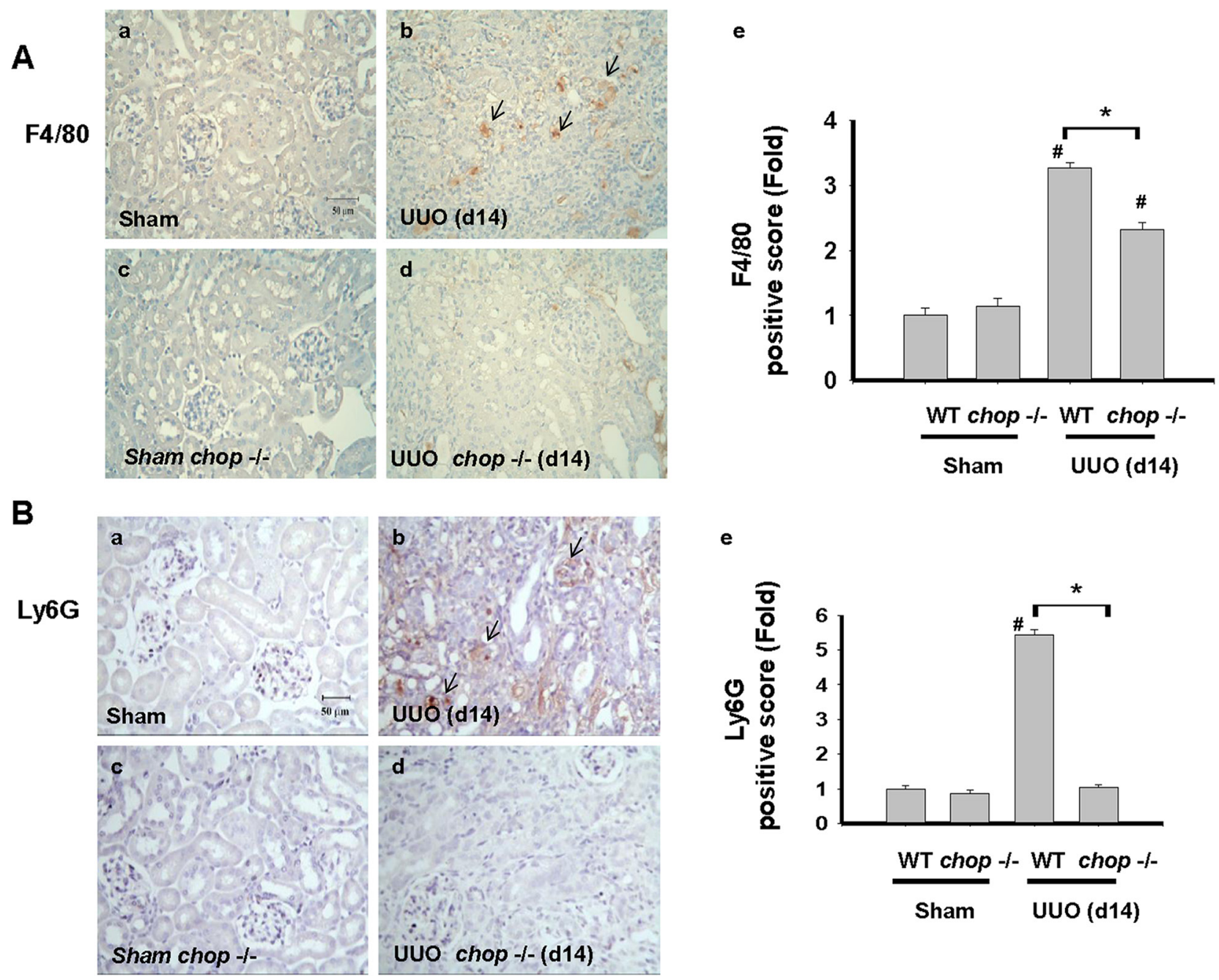

Figure 6: CHOP deficiency attenuates macrophages and neutrophils infiltration in the kidneys of UUO mice. Wild type or $C H O P$ knockout C57BL/6 micewere surgically administered UUO for 14 days. Sham control was the contralateral normal kidneys. The macrophage marker F4/80 was detected by the IHC staining and the quantification was detected in A. The neutrophil marker Ly6G was detected by the IHC staining and its quantification was shown in B. Data are presented as mean $\pm \mathrm{SEM}$ ( $\mathrm{n}=5 /$ group) for three independent experiments. $\# P<0.05$, vs wild type sham control. ${ }^{*} P<0.05$, UUO (day 14 ) wild type vs $C H O P-/-$ WT: Wild type; $C H O P-/-:$ CHOP deficiency. 
CHOP knockout mice. These results suggest that $\mathrm{CHOP}$ is an important factor for the regulation of oxidative stress induction and NOX-4 modulation, which may be involved in the UUO fibrotic process. However, investigation on detailed signaling cascade components is still needed in the future.

Renal fibrogenesis is known to be associated with leukocyte recruitment, angiogenesis, vascular leak, and myofibroblast appearance [63]. The renal myofibroblasts are thought to originate de novo in renal fibrosis in which they may represent a stressed and dedifferentiated phenotype of fibroblasts [64]. LeBleu et al. suggested that the source of myofibroblasts in kidney fibrosis included local resident fibroblasts, bone marrow differentiation, endothelial-to-mesenchymal transition, and epithelialto-mesenchymal transition [65]. Duffield has recently reviewed that the studies in FOXD1-lineage cells provide the evidence that pericytes and resident fibroblasts are the major precursors of myofibroblasts [63]. Moreover, macrophage polarization, including classically-activated M1 proinflammatory macrophages and alternative activation of macrophages (M2), can also regulate the renal fibrosis [66]. Pan et al. recently found that deficiency of M2 macrophages, but not of M1 macrophages, inhibited EMT and renal fibrosis in a mouse UUO model [67]. M2 macrophages have been suggested to be the main source in the progression of renal fibrosis (CKD) following ischemia/reperfusion injury (AKI) [68]. It has been demonstrated that the phenotypic transition of resident renal tubular cells, endothelial cells, and pericytes is involved in the UUO-induced renal fibrosis process [24]. UUO has also been found to do not affect in significant glomerular injury but shows early macrophage infiltration and interstitial fibrosis [25]. Thus, question possibly raised

\section{Sham UUO (d14)}
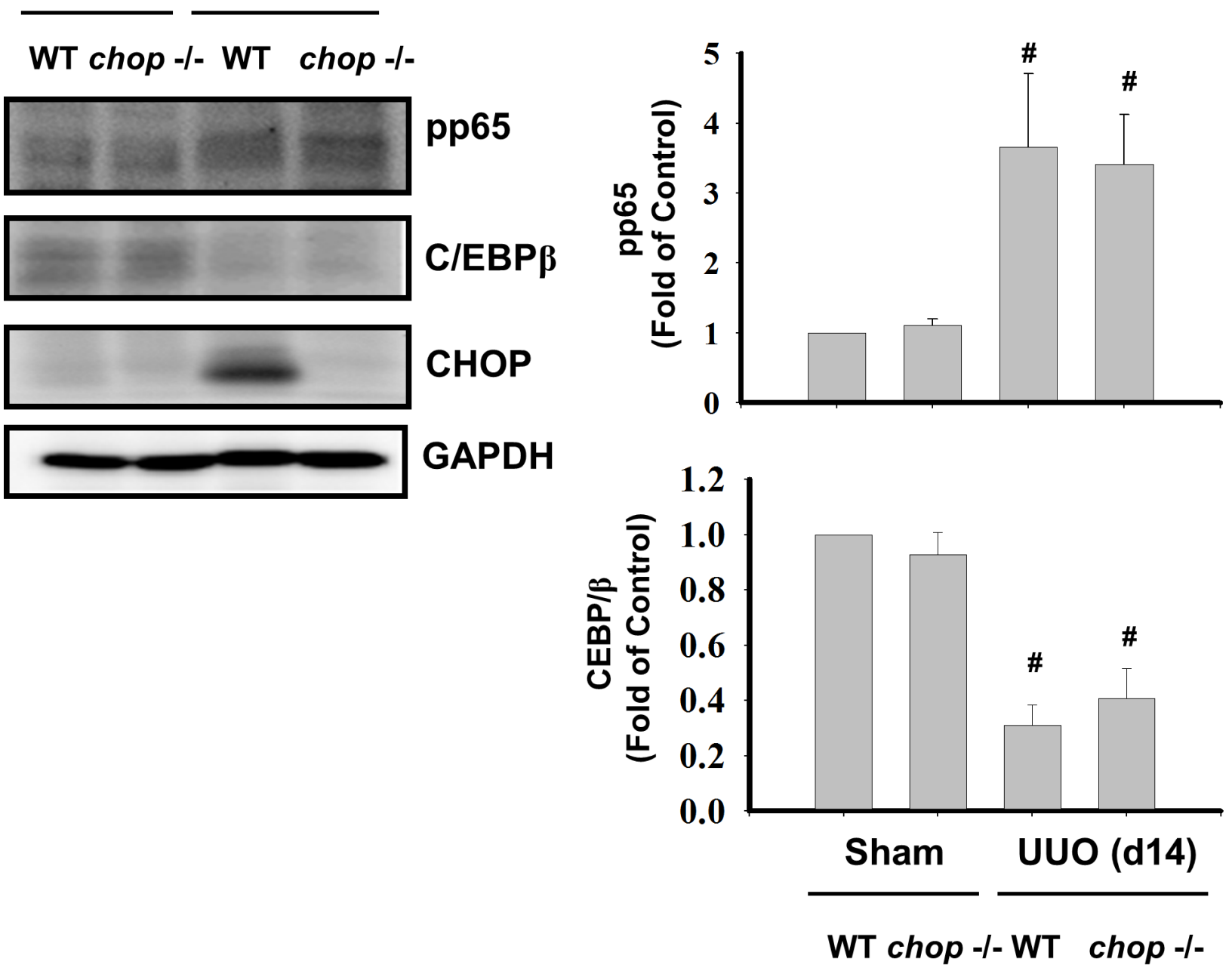

Figure 7: CHOP deficiency does not activate NFאB-p65 phosphorylation and C/EBP $\beta$ expression in the kidneys of UUO rats. Wild type or $C H O P$ knockout micewere surgically administered UUO for 14 days. Sham control was the contralateral normal kidneys. NFKB-p65 phosphorylation and C/EBP $\beta$ expression were performed by Western blotting. Data are presented as means \pm SEM ( $\mathrm{n}=5$ /group) for three independent experiments. $\# P<0.05$, vs wild type sham control. WT: Wild type; CHOP-/-: CHOP deficiency. 
in the future based on the data of current study is CHOP expressed in which cell types are critical in the context of kidney fibrosis.

Recently, Zhang et al. have shown that suppression of $\mathrm{Hmgb} 1 / \mathrm{TLR} 4 / \mathrm{NF} \kappa \mathrm{B} / \mathrm{IL}-1 \beta$ signaling pathway is involved in the CHOP deficiency-prevented UUO-induced renal fibrosis [69]. The present work also demonstrates that CHOP deficiency conspicuously attenuates obstructiveinduced renal fibrosis in UUO model. Our novel findings are that CHOP deficiency diminishes not only apoptotic cell death as well as prolonged oxidative stress but also reduces inflammation infiltration in fibrotic process. These findings indicated that CHOP signals may be a potential therapeutic target for the prevention of CKD and ESRD.

\section{MATERIALS AND METHODS}

\section{Unilateral ureteral obstruction (UUO) mouse model}

Mice deficient in $\mathrm{CHOP}\left(\mathrm{CHOP}^{-/-}\right)$on a $\mathrm{C} 57 \mathrm{BL} / 6$ background were purchased from Jackson Laboratories (Bar Harbor, ME, USA). Adult male $\mathrm{CHOP}^{-/-}$mice and WT C57BL/6 mice weighing 20-25 g (6-week-old) were used in this study. The Animal Research Committee of the College of Medicine, National Taiwan University, approved and conducted the study in accordance with the guidelines for the care and use of laboratory animals. The animals were treated humanely and with regard for alleviation of suffering. Mice were housed in a room at a constant temperature of $22 \pm 2{ }^{\circ} \mathrm{C}$ with a $12 \mathrm{~h}$ lightdark cycle. The UUO model was performed as described previously [4, 33]. Briefly, the left abdominal incision was made around in the kidney and the ureter was ligated with cotton thread. After suturing, the animals returned to the cage for adapt time point. Contralateral non-obstructed kidneys were served as the control preparations. Mice were sacrificed on 3, 7, and 14 days after UUO induction.

\section{Histological examination}

Renal tissues were isolated and fixed with $10 \%$ formaldehyde buffered with PBS, $0.01 \mathrm{M}, \mathrm{pH} 7.4$.

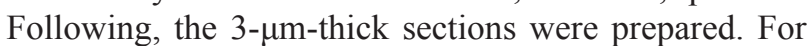
estimating renal histological injury and renal fibrosis, Masson-trichrome staining sections were used. Renal collagen deposition was as described previously [4].

\section{Immunohistochemical staining}

Three- $\mu$ m-thick sections were prepared and immunohistochemical staining was performed as described previously [4, 33]. Briefly, the sections were deparaffinized with xylene solution and $75 \%$ alcohol for $5 \mathrm{~min}$ each. After boiling for $30 \mathrm{~min}$ in sodium citrate buffer (PH 6.0), the endogenous peroxidase activity was eliminated with $3 \%$ hydrogen peroxide and the nonspecific binding reaction was blocked with 5\% goat serum for $30 \mathrm{~min}$. The sections were exposed with antifibronectin (Cat. No. 610077; BD Biosciences, San Jose, CA, USA), anti- $\alpha$-smooth muscle actin ( $\alpha$ SMA) (Cat. No. A2547; Sigma-Aldrich, St. Louis, MO, USA), antiLy6G (Cat. No. 14-5931-82; eBioscience, San Diego, CA, USA) and anti-F4/80 (Cat. No. 14-4801-82; eBioscience) monoclonal antibodies and then incubated with alkaline phosphatase-conjugated goat anti-rabbit or goat antimouse IgG. The slides were developed using $1 \% \mathrm{H}_{2} \mathrm{O}_{2}$ and $\mathrm{DAB}$ in $0.05 \mathrm{M}$ Tris-HCl ( $\mathrm{pH} 7.9)$, and counterstained with haematoxylin. At least 15 randomly visual fields were sampled from the cortex and medulla for each kidney using a $200 \mathrm{X}$ magnification. Quantification of the results was performed by imageJ software to analyze positive staining.

\section{Terminal deoxynucleotidyl transferase-mediated dUTP nick-end labeling (TUNEL) fluorescence staining}

Renal apoptotic cells were detected by the fluorometric transferase-mediated TUNEL assay (Promega, Madison, WI, USA). The TUNEL stain protocol was follow to the manufacturer instruction. Briefly, renal tissues isolated from UUO or normal mice were fixed in $10 \%$ formaldehyde and embedded in paraffin. $3-\mu \mathrm{m}$-thick sections were deparaffinized and then rehydration with alcohol. Subsequently, proteinase $\mathrm{K}$ was used to digest protein for $20 \mathrm{~min}$ and preceded to PBS wash 3 times for 10 min each. Stained the samples with TUNEL fluoresce mixture for $1 \mathrm{~h}$, and Hoechst $33258(1 \mu \mathrm{g} / \mathrm{ml})$ counter stain was followed for $15 \mathrm{~min}$. The number of apoptotic cells was counted from 15 random fields under a fluorescence microscopy with 200x magnifications.

\section{Malondialdehyde (MDA) assay}

To assess the oxidative injury in obstruction-induced renal tissues, MDA contents were measured using a MDA detection kit (Cayman, Michigan, USA). Briefly, wild type and CHOP knockout mice were sacrificed and the kidneys were isolated. Renal cortex tissues were homogenized with pestles in $300 \mu$ l RIPA buffer contained protease inhibitors, and then centrifuged at $1600 \mathrm{x}$ g for $20 \mathrm{~min}$. The supernatants were added to the reaction mixture for $1 \mathrm{~h}$, and then centrifuged at $1600 \mathrm{x} \mathrm{g}$ for $10 \mathrm{~min}$. The fluorescence was read at an excitation wavelength of $530 \mathrm{~nm}$ and an emission wavelength of $550 \mathrm{~nm}$ in a spectrofluorometer.

\section{Western blotting}

Renal cortex tissues were homogenized and lysed with the RIPA buffer. Whole cell lysates were subsequently 
centrifuged at $13,000 \mathrm{x} \mathrm{g}$ for $30 \mathrm{~min}$ and the total protein were collected. Electrophoresis, immunoblotting, and detection were done as described previously [4, 22]. Quantification of the results was performed by densitometric analysis. The relative values of each protein were normalized with GAPDH protein expression. The following primary antibodies were used: CHOP (Cat. No. SC-575), PAI-1 (Cat. No. SC-8979), phospho-N-terminal kinase (pJNK; Cat. No. SC-6254), Jun N-terminal kinase (JNK; Cat. No. SC-1648), and GAPDH (Cat. No. SC25778) from Santa Cruz (Dallas, Texas, USA); Collagen I (Cat. No. ab34710), Catalase (Cat. No. ab16731), SOD1 (Cat. No. ab13498), NADPH oxidase-4 (NOX-4; Cat. No. ab133303) from Abcam (Cambridge, MA, USA); $\alpha$ SMA (Cat. No. A2547) from Sigma-Aldrich; SOD2 (Cat. No. 13141S) from Cell Signaling (Danvers, MA, USA); Caspase 12 (Cat. No. 3282-100) from Biovision (Milpitas, CA, USA).

\section{Statistics}

The results were obtained in triplicate. Data are expressed as mean \pm SEM. All data analysis was performed by one-way analysis of variance (ANOVA) followed by post hoc analysis with Bonferroni's test. P value $<0.05$ was considered to indicate a statistically significant difference.

\section{ACKNOWLEDGMENTS}

None.

\section{CONFLICTS OF INTEREST}

The authors declare no competing financial interests.

\section{GRANT SUPPORT}

This work was supported by grants from the National Science Council (NSC 100-2314-B-002-069) and the National Taiwan University Hospital (NTUH101S-1853, NTUH102-002094 and NTUH-103-S2402).

\section{REFERENCES}

1. Becker GJ, Hewitson TD. The role of tubulointerstitial injury in chronic renal failure. Current Opinion in Nephrology and Hypertension. 2000; 9:133-138.

2. Yokoi H, Mukoyama M, Sugawara A, Mori K, Nagae T, Makino H, Suganami T, Yahata K, Fujinaga Y, Tanaka I, Nakao K. Role of connective tissue growth factor in fibronectin expression and tubulointerstitial fibrosis. American Journal of Physiology Renal Physiology. 2002; 282:F933-942.
3. Nath KA. Tubulointerstitial changes as a major determinant in the progression of renal damage. American Journal of Kidney Diseases. 1992; 20:1-17.

4. Chiang CK, Hsu SP, Wu CT, Huang JW, Cheng HT, Chang YW, Hung KY, Wu KD, Liu SH. Endoplasmic reticulum stress implicated in the development of renal fibrosis. Molecular Medicine. 2011; 17:1295-1305.

5. Wu CT, Sheu ML, Tsai KS, Weng TI, Chiang CK, Liu SH. The role of endoplasmic reticulum stress-related unfolded protein response in the radiocontrast medium-induced renal tubular cell injury. Toxicological Sciences. 2010; 114:295-301.

6. Yoshida H. ER stress and diseases. FEBS journal. 2007; 274:630-658.

7. Szegezdi E, Logue SE, Gorman AM and Samali A. Mediators of endoplasmic reticulum stress-induced apoptosis. EMBO Reports. 2006; 7:880-885.

8. Schroder M, Kaufman RJ. The mammalian unfolded protein response. Annual Review of Biochemistry. 2005; 74:739-789.

9. Vij N, Amoako MO, Mazur S, Zeitlin PL. CHOP transcription factor mediates IL-8 signaling in cystic fibrosis bronchial epithelial cells. American Journal of Respiratory Cell and Molecular Biology. 2008; 38:176-184.

10. Tamaki N, Hatano E, Taura K, Tada M, Kodama Y, Nitta T, Iwaisako K, Seo S, Nakajima A, Ikai I, Uemoto S. CHOP deficiency attenuates cholestasis-induced liver fibrosis by reduction of hepatocyte injury. American Journal of Physiology Gastrointestinal and Liver Physiology. 2008; 294:G498-505.

11. Korfei M, Ruppert C, Mahavadi P, Henneke I, Markart P, Koch M, Lang G, Fink L, Bohle RM, Seeger W, Weaver TE, Guenther A. Epithelial endoplasmic reticulum stress and apoptosis in sporadic idiopathic pulmonary fibrosis. American Journal of Respiratory and Critical Care Medicine. 2008; 178:838-846.

12. Namba $T$, Tanaka $K$, Ito $Y$, Ishihara $T$, Hoshino $T$, Gotoh T, Endo M, Sato K, Mizushima T. Positive role of CCAAT/enhancer-binding protein homologous protein, a transcription factor involved in the endoplasmic reticulum stress response in the development of colitis. American Journal of Pathology. 2009; 174:1786-1798.

13. Shirakawa K, Maeda S, Gotoh T, Hayashi M, Shinomiya K, Ehata S, Nishimura R, Mori M, Onozaki K, Hayashi H, Uematsu S, Akira S, Ogata E, Miyazono K, Imamura T. CCAAT/enhancer-binding protein homologous protein (CHOP) regulates osteoblast differentiation. Molecular and Cellular Biology. 2006; 26:6105-6116.

14. Batchvarova N, Wang XZ, Ron D. Inhibition of adipogenesis by the stress-induced protein CHOP (Gadd153). EMBO Journal. 1995; 14:4654-4661.

15. Barone MV, Crozat A, Tabaee A, Philipson L, Ron D. CHOP (GADD153) and its oncogenic variant, TLS-CHOP, 
have opposing effects on the induction of G1/S arrest. Genes \& Development. 1994; 8:453-464.

16. Oyadomari S, Mori M. Roles of CHOP/GADD153 in endoplasmic reticulum stress. Cell Death \& Differentiation. 2004; 11:381-389.

17. Rasheva VI, Domingos PM. Cellular responses to endoplasmic reticulum stress and apoptosis. Apoptosis. 2009; 14:996-1007.

18. Song B, Scheuner D, Ron D, Pennathur S, Kaufman RJ. Chop deletion reduces oxidative stress, improves beta cell function, and promotes cell survival in multiple mouse models of diabetes. Journal of Clinical Investigation. 2008; 118:3378-3389.

19. Yoshida T, Sugiura H, Mitobe M, Tsuchiya K, Shirota S, Nishimura S, Shiohira S, Ito H, Nobori K, Gullans SR, Akiba T, Nitta K. ATF3 protects against renal ischemiareperfusion injury. Journal of the American Society of Nephrology. 2008; 19:217-224.

20. Bek MF, Bayer M, Muller B, Greiber S, Lang D, Schwab A, August C, Springer E, Rohrbach R, Huber TB, Benzing T, Pavenstadt $\mathrm{H}$. Expression and function of $\mathrm{C} / \mathrm{EBP}$ homology protein (GADD153) in podocytes. American Journal of Pathology. 2006; 168:20-32.

21. Lovat PE, Corazzari M, Goranov B, Piacentini M, Redfern CP. Molecular mechanisms of fenretinide-induced apoptosis of neuroblastoma cells. Annals of the New York Academy of Sciences. 2004; 1028:81-89.

22. Chen BL, Sheu ML, Tsai KS, Lan KC, Guan SS, Wu CT, Chen LP, Hung KY, Huang JW, Chiang CK, Liu SH. CCAATEnhancer-binding protein homologous protein deficiency attenuates oxidative stress and renal ischemia-reperfusion injury. Antioxidants \& Redox Signaling. 2015; 23:1233-1245.

23. Misseri R, Meldrum DR, Dinarello CA, Dagher P, Hile KL, Rink RC, Meldrum KK. TNF-alpha mediates obstructioninduced renal tubular cell apoptosis and proapoptotic signaling. American Journal of Physiology Renal Physiology. 2005; 288:F406-411.

24. Chevalier RL, Forbes MS, Thornhill BA. Ureteral obstruction as a model of renal interstitial fibrosis and obstructive nephropathy. Kidney International. 2009; 75:1145-1152.

25. Fogo AB. Renal fibrosis: not just PAI-1 in the sky. Journal of Clinical Investigation. 2003; 112:326-328.

26. Gharaee-Kermani M, Wiggins R, Wolber F, Goyal M, Phan $\mathrm{SH}$. Fibronectin is the major fibroblast chemoattractant in rabbit anti-glomerular basement membrane disease. American Journal of Pathology. 1996; 148:961-967.

27. Borgeson E, Docherty NG, Murphy M, Rodgers K, Ryan A, O’Sullivan TP, Guiry PJ, Goldschmeding R, Higgins DF, Godson C. Lipoxin A and benzo-lipoxin A attenuate experimental renal fibrosis. FASEB Journal. 2011; 25:2967-2979.

28. Docherty NG, O'Sullivan OE, Healy DA, Fitzpatrick JM, Watson RW. Evidence that inhibition of tubular cell apoptosis protects against renal damage and development of fibrosis following ureteric obstruction. American Journal of Physiology Renal Physiology. 2006; 290:F4-13.

29. Schroder M. Endoplasmic reticulum stress responses. Cellular and Molecular Life Sciences. 2008; 65:862-894.

30. Higgins DF, Kimura K, Bernhardt WM, Shrimanker N, Akai Y, Hohenstein B, Saito Y, Johnson RS, Kretzler M, Cohen CD, Eckardt KU, Iwano M, Haase VH. Hypoxia promotes fibrogenesis in vivo via HIF-1 stimulation of epithelial-to-mesenchymal transition. Journal of Clinical Investigation. 2007; 117:3810-3820.

31. Mizuguchi Y, Chen J, Seshan SV, Poppas DP, Szeto HH, Felsen D. A novel cell-permeable antioxidant peptide decreases renal tubular apoptosis and damage in unilateral ureteral obstruction. American Journal of Physiology Renal Physiology. 2008; 295:F1545-1553.

32. He W, Wang Y, Zhang MZ, You L, Davis LS, Fan H, Yang HC, Fogo AB, Zent R, Harris RC, Breyer MD, Hao CM. Sirt1 activation protects the mouse renal medulla from oxidative injury. Journal of Clinical Investigation. 2010; 120:1056-1068.

33. Chung AC, Huang XR, Zhou L, Heuchel R, Lai KN, Lan HY. Disruption of the Smad7 gene promotes renal fibrosis and inflammation in unilateral ureteral obstruction (UUO) in mice. Nephrology Dialysis Transplantation. 2009; 24:1443-1454.

34. Dendooven A, Ishola DA, Jr., Nguyen TQ, Van der Giezen DM, Kok RJ, Goldschmeding R, Joles JA. Oxidative stress in obstructive nephropathy. International Journal of Experimental Pathology. 2011; 92:202-210.

35. Miyazaki Y, Kaikita K, Endo M, Horio E, Miura M, Tsujita K, Hokimoto S, Yamamuro M, Iwawaki T, Gotoh T, Ogawa H, Oike Y. C/EBP homologous protein deficiency attenuates myocardial reperfusion injury by inhibiting myocardial apoptosis and inflammation. Arteriosclerosis, Thrombosis, and Vascular Biology. 2011; 31:1124-1132.

36. Oyadomari S, Koizumi A, Takeda K, Gotoh T, Akira S, Araki E, Mori M. Targeted disruption of the Chop gene delays endoplasmic reticulum stress-mediated diabetes. The Journal of Clinical Investigation. 2002; 109:525-532.

37. Silva RM, Ries V, Oo TF, Yarygina O, Jackson-Lewis V, Ryu EJ, Lu PD, Marciniak SJ, Ron D, Przedborski S, Kholodilov N, Greene LA, Burke RE. CHOP/GADD153 is a mediator of apoptotic death in substantia nigra dopamine neurons in an in vivo neurotoxin model of parkinsonism. Journal of Neurochemistry. 2005; 95:974-986.

38. Zinszner H, Kuroda M, Wang X, Batchvarova N, Lightfoot RT, Remotti H, Stevens JL, Ron D. CHOP is implicated in programmed cell death in response to impaired function of the endoplasmic reticulum. Genes \& Development. 1998; 12:982-995.

39. McCullough KD, Martindale JL, Klotz LO, Aw TY, Holbrook NJ. Gadd153 sensitizes cells to endoplasmic 
reticulum stress by down-regulating $\mathrm{Bcl} 2$ and perturbing the cellular redox state. Molecular and Cellular Biology. 2001; 21:1249-1259.

40. Noh MR, Kim JI, Han SJ, Lee TJ, Park KM. C/EBP homologous protein (CHOP) gene deficiency attenuates renal ischemia/reperfusion injury in mice. Biochimica et Biophysica Acta. 2015; 1852:1895-1901.

41. Gorman AM, Healy SJ, Jager R, Samali A. Stress management at the ER: regulators of ER stress-induced apoptosis. Pharmacology \& Therapeutics. 2012; 134:306-316.

42. Endo M, Mori M, Akira S, Gotoh T. C/EBP homologous protein (CHOP) is crucial for the induction of caspase-11 and the pathogenesis of lipopolysaccharideinduced inflammation. Journal of Immunology. 2006; 176:6245-6253.

43. Yoshimura T, Matsushima K, Tanaka S, Robinson EA, Appella E, Oppenheim JJ, Leonard EJ. Purification of a human monocyte-derived neutrophil chemotactic factor that has peptide sequence similarity to other host defense cytokines. Proceedings of the National Academy of Sciences of the United States of America. 1987; 84:9233-9237.

44. Summers SA, van der Veen BS, O'Sullivan KM, Gan PY, Ooi JD, Heeringa P, Satchell SC, Mathieson PW, Saleem MA, Visvanathan K, Holdsworth SR, Kitching AR. Intrinsic renal cell and leukocyte-derived TLR4 aggravate experimental anti-MPO glomerulonephritis. Kidney International. 2010; 78:1263-1274.

45. Baggiolini M, Dewald B, Moser B. Interleukin- 8 and related chemotactic cytokines--CXC and CC chemokines. Advances in Immunology. 1994; 55:97-179.

46. Aggarwal A, Baker CS, Evans TW, Haslam PL. G-CSF and IL-8 but not GM-CSF correlate with severity of pulmonary neutrophilia in acute respiratory distress syndrome. The European Respiratory Journal. 2000; 15:895-901.

47. Duymelinck C, Dauwe SE, De Greef KE, Ysebaert DK, Verpooten GA, De Broe ME. TIMP-1 gene expression and PAI-1 antigen after unilateral ureteral obstruction in the adult male rat. Kidney International. 2000; 58:1186-1201.

48. Akin M, Demirbilek S, Ay S, Gurunluoglu K, Turkmen E, Tas E, Aksoy RT, Baykarabulut A, Edali MN. Attenuation of ureteral obstruction-induced renal injury by polyenylphosphatidylcholine. International Journal of Urology. 2007; 14:350-356.

49. Tashiro K, Tamada S, Kuwabara N, Komiya T, Takekida K, Asai T, Iwao H, Sugimura K, Matsumura Y, Takaoka M, Nakatani T, Miura K. Attenuation of renal fibrosis by proteasome inhibition in rat obstructive nephropathy: possible role of nuclear factor kappaB. International Journal of Molecular Medicine. 2003; 12:587-592.

50. Li ZI, Chung AC, Zhou L, Huang XR, Liu F, Fu P, Fan JM, Szalai AJ, Lan HY. C-reactive protein promotes acute renal inflammation and fibrosis in unilateral ureteral obstructive nephropathy in mice. Laboratory Investigation. 2011; 91:837-851.

51. Du S, Hiramatsu N, Hayakawa K, Kasai A, Okamura M, Huang T, Yao J, Takeda M, Araki I, Sawada N, Paton AW, Paton JC, Kitamura M. Suppression of NF-kappaB by cyclosporin a and tacrolimus (FK506) via induction of the $\mathrm{C} / \mathrm{EBP}$ family: implication for unfolded protein response. Journal of Immunology. 2009; 182:7201-7211.

52. Hayakawa K, Nakajima S, Hiramatsu N, Okamura M, Huang T, Saito Y, Tagawa Y, Tamai M, Takahashi S, Yao J, Kitamura M. ER stress depresses NF-kappaB activation in mesangial cells through preferential induction of C/EBP beta. Journal of the American Society of Nephrology. 2010; 21:73-81.

53. Chiang CK, Sheu ML, Lin YW, Wu CT, Yang CC, Chen MW, Hung KY, Wu KD, Liu SH. Honokiol ameliorates renal fibrosis by inhibiting extracellular matrix and proinflammatory factors in vivo and in vitro. British Journal of Pharmacology. 2011; 163:586-597.

54. De Minicis S, Seki E, Paik YH, Osterreicher CH, Kodama Y, Kluwe J, Torozzi L, Miyai K, Benedetti A, Schwabe $\mathrm{RF}$, Brenner DA. Role and cellular source of nicotinamide adenine dinucleotide phosphate oxidase in hepatic fibrosis. Hepatology. 2010; 52:1420-1430.

55. Sedeek M, Callera G, Montezano A, Gutsol A, Heitz F, Szyndralewiez C, Page P, Kennedy CR, Burns KD, Touyz RM, Hebert RL. Critical role of Nox4-based NADPH oxidase in glucose-induced oxidative stress in the kidney: implications in type 2 diabetic nephropathy. American Journal of Physiology Renal Physiology. 2010; 299:F1348-1358.

56. Crestani B, Besnard V, Boczkowski J. Signalling pathways from NADPH oxidase-4 to idiopathic pulmonary fibrosis. International Journal of Biochemistry \& Cell Biology. 2011; 43:1086-1089.

57. Wu CT, Sheu ML, Tsai KS, Chiang CK, Liu SH. Salubrinal, an eIF2alpha dephosphorylation inhibitor, enhances cisplatin-induced oxidative stress and nephrotoxicity in a mouse model. Free Radical Biology \& Medicine. 2011; 51:671-680.

58. Galan M, Kassan M, Kadowitz PJ, Trebak M, Belmadani S, Matrougui K. Mechanism of endoplasmic reticulum stressinduced vascular endothelial dysfunction. Biochimica et Biophysica Acta. 2014; 1843:1063-1075.

59. Galan M, Kassan M, Choi SK, Partyka M, Trebak M, Henrion D, Matrougui K. A novel role for epidermal growth factor receptor tyrosine kinase and its downstream endoplasmic reticulum stress in cardiac damage and microvascular dysfunction in type 1 diabetes mellitus. Hypertension. 2012; 60:71-80.

60. Pedruzzi E, Guichard C, Ollivier V, Driss F, Fay M, Prunet C, Marie JC, Pouzet C, Samadi M, Elbim C, O'dowd Y, Bens M, Vandewalle A, Gougerot-Pocidalo MA, Lizard $\mathrm{G}$, Ogier-Denis E. NAD(P)H oxidase Nox-4 mediates 7-ketocholesterol-induced endoplasmic reticulum stress and 
apoptosis in human aortic smooth muscle cells. Molecular and Cellular Biology. 2004; 24:10703-10717.

61. Yokouchi M, Hiramatsu N, Hayakawa K, Okamura M, Du S, Kasai A, Takano Y, Shitamura A, Shimada T, Yao J, Kitamura M. Involvement of selective reactive oxygen species upstream of proapoptotic branches of unfolded protein response. Journal of Biological Chemistry. 2008; 283:4252-4260.

62. Santos CX, Nabeebaccus AA, Shah AM, Camargo LL, Filho SV, Lopes LR. Endoplasmic reticulum stress and Nox-mediated reactive oxygen species signaling in the peripheral vasculature: potential role in hypertension. Antioxidants \& Redox Signaling. 2014; 20:121-134.

63. Duffield JS. Cellular and molecular mechanisms in kidney fibrosis. Journal of Clinical Investigation. 2014; 124:2299-2306.

64. Boor P, Floege J. The renal (myo-)fibroblast: a heterogeneous group of cells. Nephrology Dialysis Transplantation. 2012; 27:3027-3036.
65. LeBleu VS, Taduri G, O'Connell J, Teng Y, Cooke VG, Woda C, Sugimoto H, Kalluri R. Origin and function of myofibroblasts in kidney fibrosis. Nature Medicine. 2013; 19:1047-1053.

66. Meng XM, Nikolic-Paterson DJ, Lan HY. Inflammatory processes in renal fibrosis. Nature Reviews Nephrology. 2014; 10:493-503.

67. Pan B, Liu G, Jiang Z, Zheng D. Regulation of renal fibrosis by macrophage polarization. Cell Physiol Biochem. 2015; 35:1062-1069.

68. Kim MG, Kim SC, Ko YS, Lee HY, Jo SK, Cho W. The role of M2 macrophages in the progression of chronic kidney disease following acute kidney injury. PLoS One. 2015; 10: e0143961.

69. Zhang M, Guo Y, Fu H, Hu S, Pan J, Wang Y, Cheng J, Song J, Yu Q, Zhang S, Xu JF, Pei G, Xiang X, et al. Chop deficiency prevents UUO-induced renal fibrosis by attenuating fibrotic signals originated from Hmgb1/TLR4/ NFкB/IL-1 $\beta$ signaling. Cell Death \& Disease. 2015; 6:e1847. 